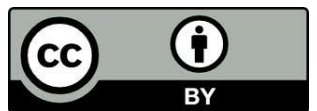

\title{
THE INTERDISCIPLINARY STUDY OF GEOGRAPHY AND RELIGION: A PRAGMATIC APPROACH
}

\author{
O Estudo Interdisciplinar de Geografia e Religião: Uma Aproximação Pragmática
}

Thomas A. Tweed

President-elect, American Academy of Religion W. Harold and Martha Welch Endowed Chair Department of American Studies University of Notre Dame, USA ttweed@nd.edu

\begin{abstract}
Scholars in every field have presuppositions, including assumptions about the nature of truth and the status of theory, and, drawing on my own spatial theory of religion, I begin by asking which philosophical framework seems most promising for the interdisciplinary study of geography and religion. I argue that pragmatism, especially as it found expression in the later writing of the philosopher Hilary Putnam, can be useful for answering some of the most vexing epistemological questions. To show the utility of my theory, and its pragmatist perspective on fundamental questions about meaning, truth, and interpretation, I end by considering its implications for the interdisciplinary study of geography and religion and identify some guiding theoretical principles.
\end{abstract}

Keywords: Pragmatism, Putnam, Geography, Religion, Theory, Method, Place, Displacement

RESUMO: Estudiosos em cada campo possuem pressuposições, incluindo noções sobre a natureza da verdade e do status da teoria, assim, partindo de minha própria teoria espacial da religião, comecei a questionar qual matriz filosófica parece ser mais promissora para o estudo interdisciplinar da geografia e religião. Defendo que o pragmatismo, especialmente aquele expresso nos últimos escritos do filósofo Hilary Putnam, pode ser útil para responder algumas das mais incomodas questões epistemológicas. Para evidenciar a utilidade de minha teoria, e sua perspectiva pragmática em questões fundamentais sobre sentido, verdade e interpretação, arremato considerando suas implicações para o estudo interdisciplinar da geografia e religião, bem como identifico alguns princípios teóricos norteadores.

Palavras chave: Pragmatismo, Putnam, Geografia, Religião, Teoria, Método, Lugar, Displacement 
Questions animate fields of study. Answers, however tentative, are welcome, of course; but it is the questions we ask that matter most. I have asked many questions since I began studying religion, but since 1991 I have wondered a good deal about geography and religion. To put it most simply, I have been asking: where is religion? Most specialists in religious studies seem more concerned with other questions: When is religion? In what ways has it changed over time? What is it? What are its diverse forms? How is religion expressed? How does it come to be practiced and transmitted in this way and not that way? And why is religion? Why do humans turn to religion? Where does the impulse originate and will it continue? I care about those questions too, but since 1991, when I first started to study religious practice at a Cuban Catholic shrine in Miami, inquiries about place have emerged as central for me. That is because the Cuban exiles I met during five years of fieldwork at the Shrine of Our Lady of Charity, which honors the national patroness of Cuba, seemed preoccupied with where they were and where they used to be. They wept as they told me about their former lives on the island, and they grinned as they imagined their return from exile. As I argued in my ethnography about the shrine, for them religion was translocative, a term I coined to make sense of what I found during fieldwork: religious rituals, tropes, narratives, institutions, and artifacts propelled them back and forth between the homeland and the new land (TWEED, 1997).

Shortly after I started studying those transnational migrants I decided I needed to learn more about locality. I knew that some theorists of religion had considered the topic. Phenomenologists of religion had talked about "sacred space" (ELIADE, 1959; VAN DER LEEUW, 1986). Jonathan Z. Smith, a critic of Mircea Eliade's work and one of the most influential scholars of the past two decades, also used spatial language: for example, as he compared "locative" and "utopian" forms of piety (SMITH, 2004, p.14-16). More recently, Ann Taves and other scholars who have written about religious studies theory and method endorsed Emil Durkheim's starting point for understanding "religion," and used spatial metaphors to analyze "things set apart as special" (TAVES, 2009, p.28-48). That North American scholar has not focused on geography, but other scholars on both sides of the Atlantic have considered space and place more fully. In fact, some observers have suggested that "since the 1980s the geography of religion has been an emerging field of study in France, Germany, and Britain” (ALLES, 2008, p.36; 
see Vincent et al., 1995; Bertrand and Muller, 1999; Rinschede, 1999; Park, 1994). Veikko Anttoten in Finland as well as Kim Knott in Britain, two important European religion scholars who have analyzed religion's spatial dynamics, have made especially important methodological and theoretical contributions to the geography of religion since the mid-1990s (KNOTT, 2005; 2008; ANTTONEN, 1996; 2005).

Some scholars in Religious Studies' subfields also have analyzed space and place. For example, those who have studied pilgrimage and landscape in India and have cited geographer Surinder Mohan Bhardwaj's influential 1973 volume, Hindu Places of Pilgrimage in India (BHARDWAJ, 1973; ECK, 1998; GOLD, 1988; HABERMAN, 1994); and some India specialists have engaged the geographical scholarship even more fully (FELDHAUS, 2003). In my area of specialization, North American religions, a few scholars have taken geography and geographers seriously, especially historians that have focused on demographics, migration, landscape, shrines, museums, and memorials (GAUSTAD; BARLOW, 2001; CHIDESTER; LINENTHAL, 1995; CARROLL, 2000; LANE, 1988; 2001; LINENTHAL，1991; 1997; 2001; BREMMER, 2004; KAELL, 2014). Among the most influential contributions, David Chidester and Edward Linenthal offered an overview in their collection on American Sacred Space (CHIDESTER; LINENTHAL, 1995, p.1-42), and Belden Lane delineated "three models for understanding American sacred space" (LANE, 2001).

The geography of religion, however, is not yet a distinct subfield in Religious Studies, although there are some institutional signs of interest in the topic. Consider the annual meeting of the American Academy of Religion, the largest professional organization for scholars of religion in North America. In 2014, there were conference sessions organized by the Space, Place, and Religion Group as well as several other groups that focus on spatial themes: Religion and Cities, Religion and Ecology, and Religion and Migration (AAR Program Book). There also were conferences and workshops in Europe dedicated to religion and geography, and some journals published special issues on the topic (ANTTONEN; HOLM, 2005; STAUSBERG, 2009).

With a few exceptions, the most influential religious studies reference works have ignored or de-emphasize the geographical study of religion. The multi-volume Encyclopedia of Religion, perhaps the most widely consulted English-language reference work, included a four-page entry on "geography" in its first edition, though its 
author failed to cite any major text in Human Geography, and that entry remained unrevised in the second edition, though seven new references were added, including geographer Chris C. Park's Sacred Worlds (ELIADE, 1987, p.509-512; JAMES, 1955 , p.3433-3437). Jonathan Z. Smith's influential Harper Collins Dictionary of Religion included no entry on "geography" and failed to mention that emerging subfield in its surveys of approaches to the study of religion - anthropological, phenomenological, philosophical, psychological, and sociological (SMITH, 1995). Some more recent reference works have not done better. No entry on "geography," "space," or "place" can be found among the thirty-one key words listed in the Guide to the Study of Religion (BRAUN; MCCUTCHEON, 2000). The Routledge Companion to the Study of Religion did not include the geography of religion among its nine entries on "key approaches to the study of religions" (HINNELS, 2009); neither did The Blackwell Companion to the Study of Religion, which listed the same number of "approaches" (SEGAL, 2006). Only the entry on "Territory" in Critical Terms for Religious Studies (GILL, 1998) and the reflection on "Spatial Methods" in The Routledge Handbook of Research Methods in the Study of Religion (KNOTT, 2011) correct this lack of systematic attention.

Since there have been somewhat limited resources available in religious studies, as I have tried to think more about the where of religion I also have turned to other fields. There was a widely reported "spatial turn" in cultural theory (TWEED, 2006, p.9-10; SOJA, 1989; CRANG; THRIFT, 2000, p.11; SAYER, 2000, p.108; BOSTEELS, 1996, p.146; KNOTT, 2008, p.1103), and some of that theory can be applied usefully to the study of religion and location. Many of the most influential sociologists of religion, including Grace Davie, Christian Smith, and Danièle HervieuLéger, have devoted their energy to thinking about secularity and modernity and have not highlighted locality in their work, but some sociologists who study urban life and transnational migration have noticed how religion shapes local landscapes and affects diasporic identity (WARNER; WITNER, 1998; CARNES; YANG, 2004; MOONEY, 2009). Cultural anthropologists, especially those who analyze globalization and trace the movement of people, goods, and practices across borders, also have provided insights (CLIFFORD, 1997; APPADURAI, 1996; INDA; ROSALDO, 2002; GUPTA; FERGUSON, 1997), as have religion scholars who are in conversation with those analysts of globalization (ROCHA; VÁSQUEZ, 2014). Some archeologists, especially 
those who favor "historical-processual" archeology (PAUKETAT, 2003, p.39), also have advanced the discussion about religion and geography.

Of course, the study of space, place, and religion is most fully developed in geography circles, where it often is viewed as a subfield of Cultural Geography or Human Geography. As one geographer has observed, however, "there is disagreement as to whether geographical research has seriously included religion" (PROCTOR, 2006, p.165). Some suggest, as one geographer did in 2009, that "in the past four or five decades, religion has tended to be marginalized as an area of study in human geography and within many of the social sciences" (DANDO, 2009). Others paint a somewhat rosier picture, as with Lily Kong, who has authored the most comprehensive reviews of the subfield's literature (KONG, 1990; 2001; 2010; see also SOPHER, 1981; LEVINE, 1986). Kong, one of the most productive geographers of religion, has taught in a geography department in Singapore, and specialists in other parts of the world also have made contributions to this transnational subfield, for example, Gisbert Rinschede in Germany, Chris Park in Britain, and Sylvio Fausto Gil Filho in Brazil (RINSCHEDE, 1999; PARK, 1994; GIL FILHO, 2008).

Despite the contradictory assessments of the subfield by specialists, it seems to me as a sympathetic outsider that there are signs of interest in spatial analyses of religion among geographers, perhaps more interest than in religious studies circles. Geography periodicals have dedicated special issues to the topic, including the Journal of Cultural Geography (1986), Social and Cultural Geography (2002), International Journal of Urban and Regional Research (2002), Population, Space, and Place (2005), Geopolitics (2006), GeoJournal (2006), Annals of the Association of American Geographers (2006), and Mobility (2008) (see STUMP, 1986; PROCTOR, 2006; HOLLOWAY; VALINS, 2002; OLSON; SILVEY, 2006). Reference works, including The Dictionary of Human Geography, contain entries on the "geography of religion" (JOHNSTON et al., 2000, p.697-699). The Association of American Geographers has a "Geography of Religions and Beliefs Systems Specialty Group," which has an online discussion list and publishes a newsletter, Geography of Religion and Belief Systems (PARK, 1994, p.20). Several volumes have synthesized the research and constituted the geographical subfield, including Pierre Deffontaines' Géographie et Religions, David 
Sopher's Geography of Religions, Gisbert Rinschede's Religionsgeographie, Chris Park's Sacred Worlds, and Roger Stump's Geography of Religion.

Research in Cultural Geography helped as I tried to interpret emplacement and displacement in my study of the Cuban shrine, and, in fact, my first public attempt to convey the results of my research were offered at a meeting of the Association of American Geographers, where I initially used the work of geographers, including Yi-Fu Tuan's and John K. Wright's analysis of "geopiety," to begin to make sense of the Cuban exiles' grins and tears. During and after my field research at the Miami shrine, interpretations of religion's spatial dynamics by scholars trained in Geography Departments - as well as works by religion scholars - have shaped my thinking.

Even if the study of geography and religion is somewhat less firmly established in religious studies than in geography, there are indications that it is an emerging subfield situated at the intersection of those two disciplines - and several others in the natural and social sciences. ${ }^{1}$ And as with all areas of study, this multidisciplinary specialization is animated by its questions. Some inquiries seem more fundamental than others, however, especially for a subfield that has such a brief and contested history. In this brief essay, I want to ask a few of those foundational questions, even if I only can propose the most cursory answers. Whether they do so self-consciously or not, scholars in every field enact presuppositions, including assumptions about the nature of truth and the status of theory, and, drawing on my own spatial theory of religion (TWEED, 2006; 2011), I begin by asking which philosophical framework seems most promising for the study of geography and religion. I suggest that pragmatism, especially as it found expression in the later writing of the philosopher Hilary Putnam, can be useful for answering some of the most vexing epistemological questions and for establishing some research guidelines (TWEED, 2006, p.7-27). That pragmatist approach, as it informed my own theory of religion, has implications for how we study religion and locality. Moving toward possible applications, I conclude by proposing theoretical principles for this emerging cross-disciplinary area of study.

\footnotetext{
${ }^{1}$ I prefer Chris Park's label for the area of study - Geography and Religion as opposed to Geography of Religion - since it allows for more diverse articulations of its aims, topics, and approaches (PARK, 1994, p.xiii).
} 


\section{Pragmatism and the Study of Religion, Place, and Displacement}

The term "pragmatism" was coined by William James in 1898 to name a philosophical perspective that had emerged twenty years earlier and would go on to have influence among intellectuals in the United States - and among some followers in Europe-between the 1910s and the 1940s and again during and after the 1980s (JAMES, 1955; PEIRCE, 1878; HOLLINGER; DEPEW, 1995, p.32). ${ }^{2}$ This philosophical movement has attracted some interest throughout Europe, including among those aligned with the Nordic Pragmatism Network, Groupe d'Études sur le Pragmatisme et la Philosophie Américaine, and the Central European Pragmatist Forum.

Historians - and pragmatists themselves - have distinguished pragmatism's defining commitments, chief advocates, and historical stages. Some interpreters have identified the movement's major "theses" (THAYER, 2010), defining "features" (WIENER, 1949), and characteristic "components" (DAVIS, 2009). Others have noted the pragmatist tradition's "general tendencies"-practicality, voluntarism, moralism, flexibility, and openness (HOLLINGER; DEPEW, 1995, p.28). One scholar of religion who has identified himself with the movement, Cornell West, has suggested that all pragmatists affirm "epistemic anti-foundationalism," the view that there are no unmediated facts or neutral interpretations and the idea that meaning can be understood in terms of effects. Yet they disagree on other matters, including how much to worry about cognitive relativism (HOLLINGER; DEPEW, 1995, p.315-316). Using that question as a standard, West distinguished (1) "conservative pragmatists," like Charles Sanders Peirce and Hilary Putnam, who worry about relativism and affirm some form of philosophical realism; (2) "moderate pragmatists," such as John Dewey and William James, who are untroubled by relativism and affirm a "minimalist realism;" and (3) "avant-garde pragmatists," like Richard Rorty, who share the moderates' lack of concern about relativism and move more fully toward an "anti-realist" position

2 Critics of pragmatism emerged soon after James coined the term, and ten years later one historian of ideas, Arthur O. Lovejoy, pointed to one of the criticisms - that there was "a multiplicity of meanings in pragmatism" (5). Lovejoy made the point by listing "the thirteen pragmatisms" in his 1908 article. The movement - and it had become a movement by then — entailed thirteen different claims, he suggested, though those could be reduced to several competing propositions about meaning, truth, knowledge, and reality (p.37-38). 
(HOLLINGER; DEPEW, 1995, p.315-316; see also HAACK, 1995; KUCKLICK, 2001, p.95-96). David Depew and Robert Hollinger, co-editors of an important book on the history of the movement, have offered another useful typology and periodization. They have identified three stages: (1) classical pragmatism, which emerged in the latenineteenth and early-twentieth century in the writings of James and Dewey; (2) positivist pragmatism, which predominated in the middle decades of the twentieth century as some positivists and analytical philosophers like Rudolf Carnap and W.V.O. Quine took a pragmatic turn; and (3) postmodern pragmatism, a third phase that can be dated from the publication of Richard Rorty's Philosophy and the Mirror of Nature in 1979 (HOLLINGER; DEPEW, 1995).

The Pragmatic movement, which emerged as a moral response to the horrors of the U.S. Civil War, an intellectual response to the promise and peril of science, and an attempt to justify religion in light of these and other developments (MENAND, 2001; HOLLINGER; DEPEW, 1995; KUKLICK, 2001; LEVINSON, 1981), was an approach to settling philosophical questions more than a full-blown philosophical system. James himself emphasized this in his 1907 volume, Pragmatism. "The pragmatic method," he suggested, "is primarily a method of settling metaphysical disputes that otherwise might be interminable" (JAMES, 1992, p.42). He meant, for example, debates about human freedom and naturalistic determinism and disputes between those that offered "materialist" interpretations of the world that explained away religion and those that defended "spiritualist" accounts of the nature of things. "The pragmatic method in such cases," he explained, "is to try to interpret each notion by tracing its respective practical consequences. What difference would it practically make to any one if this notion rather than that notion were true" (JAMES, 1992, p.42)? Extending and revising insights offered in Peirce's famous 1878 article, "How to Make Our Ideas Clear," James proposed an understanding of meaning and truth that emphasized the effects of beliefs. Pragmatism, then, is "an attitude of orientation": "The attitude of looking away from first things, principles, 'categories,' supposed necessities, and of looking towards last things, fruits, consequences, facts" (JAMES, 1955, p.46). This view has implications, as James noted, for understanding not only meaning and truth but interpretation and theory: "Theories thus become instruments, not answers to enigmas in which we can rest" (JAMES, 1955, p.46). 
This pragmatic approach, especially its epistemologically "moderate" form as it was revised and refined by Putnam during and after the 1970s, offers aid to scholars who study geography and religion. From the Religious Studies side, specialists in philosophy of religion and constructive theology have explored the pragmatic tradition-though there has been limited interest in Putnam's thought. ${ }^{3}$ Pointing to Rorty's later work on religion as well as the writings of Wayne Proudfoot and Jeffrey Stout, one scholar has suggested that there has been "a pragmatic turn in the study of religion" during the past twenty-five years in North America (DAVIS, 2009; 2012; RORTY, 2003). Yet none of the religion scholars influenced by the pragmatist tradition have focused on geographical questions. And, in turn, the Religious Studies scholars who do study space and place have not yet pondered the possible implications of pragmatism for their work.

Some geographers have incorporated a version of pragmatism in their research, even if they also have not considered the significance of Putnam's philosophy. None of the major overviews of geography and religion-from Deffontaines' Géographie et Religions to Stump's Geography of Religion-discussed pragmatism. A few scholars in other geographical subfields have gestured toward that philosophical tradition, however. Citing Peirce and Rorty and distilling pragmatism into an emphasis on the "practical value" of science, one specialist in geomorphology has argued that physical geography could profit by engaging the philosophical tradition: "A pragmatic focus on methodology and the practical utility of scientific knowledge is important, especially given the current political climate emphasizing the need for all areas of science, including physical geography, to demonstrate their practical value to society" (RHOADS, 1999, p.761). For different purposes, some economic geographers have suggested that scholars "engage philosophical discourse," and pragmatism in particular (SUNLEY, 1996). Elevating sociologist Robert E. Park and other precursors of contemporary urban geography as exemplars, some social geographers also have proposed a turn to pragmatism (JACKSON; SMITH, 1984).

\footnotetext{
${ }^{3}$ North American scholars of religion-philosophers, historians, and theologians — who have engaged pragmatism include Jeffrey Stout, Wayne Proudfoot, G. Scott Davis, Henry Levinson, David Lamberth, Nancy Frankenberry, Cornell West, William Hart, Gail Hamner, and Sheila Davaney. Although the editor uses a rather inclusive standard for defining the tradition, see also Stuart Rosenbaum's collection (ROSENBAUM, 2003).
} 
Other human geographers have too. Because it "combines the scientific method with humanistic geography," John W. Frasier argued in 1981 that pragmatism was an apt philosophical approach (FRASIER, 1981, p.72). He was especially drawn to the movement because it provided a framework for rejecting "the positivistic viewpoint of 'value-free research"” and for focusing research on "purposeful human problems," such as the deterioration of low-income housing in urban centers (FRASIER, 1981, p.66-72). Citing Frazier's article but focusing more on pragmatism's implications for facing epistemological issues and methodological challenges, Susan J. Smith, also co-author of the book in social geography that trumpeted pragmatism, decried the discipline's "curious" neglect of pragmatism and advocated the movement as a useful philosophical framework for a "humanistic geography" that emphasizes participant observation (SMITH, 1984, p.360). ${ }^{4}$

Smith explored pragmatism's implications for four issues in geographical discourse, including the structure-agency debate, but I am most interested in her attention to pragmatism's epistemological commitments and their implications for method and theory. As Smith notes, most pragmatists view theories as instrumentalmore or less useful and not true or false - and they understand interpretations as always provisional and always tied to the interpreter's values (SMITH, 1984, p.361-363). It is in proposing these compelling answers to foundational questions about the position of the interpreter, the task of interpretation, and the nature of theory that pragmatism offers aid for scholars who study geography and religion.

\section{A Pragmatic Theory of Religion's Spatial Practices: Religion as Crossing and Dwelling}

Standing at the Shrine of Our Lady of Charity - and at the annual feast day rosary and mass in a downtown Miami stadium-I began to formulate my pragmatic theory of religion (TWEED, 2006, p.1-28). It emerged as I tried to articulate what I found lacking in other theories. To make sense of the practices of those transnational

\footnotetext{
${ }^{4}$ Some reference works in Geography briefly consider the "sporadic but neither consistent nor concerted attempts to draw upon pragmatist writers" (BURNS, "Pragmatism," in JOHNSTON et al., 2000, p.632$34)$.
} 
Cuban migrants, I decided, I needed a different theory of religion, a self-consciously positioned sighting that highlights movement and relation. I cannot lay out that theory here, but let me offer my definition of religion and briefly explain a few of its most important commitments.

As I understand them, "religions are confluences of organic-cultural flows that intensify joy and confront suffering by drawing on human and surpahuman forces to make homes and cross boundaries" (TWEED, 2006, p.54). This definition draws on aquatic metaphors in order to emphasize movement, avoid essentialism, and acknowledge contact. Each religion, then, is a flowing together of currents-some institutionally enforced as "orthodox"-traversing multiple fields, where other religions, other transverse confluences, also cross, thereby creating new spiritual streams. Religions cannot be reduced to economic forces, social relations, or political interests, but religions always emerge from the swirl of transfluvial currents, as both religious and non-religious streams propel religious flows. These flows are "organiccultural," in my view, so I invoke the hyphen to suggest that both natural forces and cultural processes are at work in religion: we can talk about constraining organic channels and shifting cultural currents. So religions are processes in which social institutions bridge organic constraints and cultural mediations to produce reference frames that yield a variety of representations (tropes, artifacts, rituals, and narratives) that draw on suprahuman agents (gods, angels, demons, and so on) and imagine an ultimate horizon of human life (for example, Amida Buddha's Pure Land or the Kingdom of God). It is this appeal to suprahuman agents and an ultimate horizon that distinguishes religion from non-religion, in my view.

If this is what religion is, how does it function? I suggest, first, that religion "intensifies joy and confronts suffering." That is to say, religions involve emotion as well as cognition. Religions not only interpret and ease suffering-disease, disaster, and death - but also provide ways for humans to imagine and enhance the joys derived from encounters with the natural world, including comets and rainbows, and transitions in the lifespan, including childbirth and marriage. Religions provide that idiom and transmit those practices. Religions, in other words, are about enhancing the wonder as much as about wondering about evil (TWEED, 2006, p.69-73). 
Second, shifting to spatial metaphors, I suggest that religions "make homes and cross boundaries" (TWEED, 2006, p.73-77). Religions are about finding one's place (dwelling) and moving across space (crossing). As dwelling, religions are spatial practices - mapping, building, and inhabiting - that orient humans in time and space, situating devotees in four chronotopes, or time-spaces: the body, the home, the homeland, and the cosmos. They function, I suggest, as watch and compass. But religions make sense of the nomadic as well as the sedentary in human life and involve another spatial practice — crossing. Religions enable and constrain corporeal, terrestrial, and cosmic crossings. They mark and traverse the boundaries of not only the natural terrain, as in pilgrimages and missions, and the limits of embodied life, including illness and death, but they also chart and cross the ultimate horizon, whether that final crossing is imagined as transport or transformation, as ascending to heaven or attaining enlightenment.

\section{Toward the Interdisciplinary Study of Religion and Locality: Theoretical Principles}

In earlier work I have proposed that my theory-and its pragmatist perspective on the foundational questions about meaning, truth, and interpretation - can yield an account of space's defining features: space, I have suggested, is differentiated, kinetic, interrelated, generated, and generative (TWEED, 2011). That theory also can yield methodological principles, as we try to clarify what it might mean to "follow the flows" of religion (TWEED, 2014). But I would like to conclude by suggesting that my interpretative model also might yield a few tentative guidelines for the interdisciplinary study of religion and locality.

1. Cultivate Theoretical Modesty: Theories are positioned sightings from particular sites that are more or less useful. They are also always partial and tentative. There is no omnispection, and there are always blinds spots, sites where sightings are obscured. This does not mean there can be no knowledge, but only no view from everywhere at once or nowhere in particular. It means that scholars should be aware of their limits and modest about their claims. So self- 
conscious positioning is important, and, as I suggest below in principles 3 and 4, so is openness to multiple research topics and diverse methods of study. In this perspective, which rejects correspondence theories of truth, assessment is based on a theory's internal coherence and pragmatic value. Theories that are not as coherent and useful can be revised or discarded, and the researcher can go in search of models that are more adequate.

2. Recognize the Entanglement of Fact and Value: To mention the assessment of theories and the position of the theorist is to gesture toward another important principle: fact and value are "entangled," to use Putnam's term (2002, p.28-45). It can be useful to distinguish between factual claims and value judgments, but that distinction is not helpful when framed as the difference between the “objective" and the "subjective." As Putnam and other pragmatists have argued, fact and value intertwine, and both moral and epistemic values-for example, simplicity and coherence-are introduced as we assess theories and interpretations. We might appeal to a variety of values in the assessment of interpretations in the study of geography and religion, I suggest: professional utility, internal coherence, methodological self-consciousness, theoretical generativity, definitional adequacy, analytical complexity, historical relevance, social justice, and gender inclusiveness. Further, to appeal to these values, and recognize the entanglement of fact and value, also is to be sensitive to the ways that power as well as meaning is negotiated in our interpretations. ${ }^{5}$

3. Accept Methodological Diversity: Following from the first two principles, we should accept diverse approaches. Put aside the anxieties expressed in some reviews of the subfield about the "disarray" and "fragmentation" of the geography of religion (TUAN, 1976; STUMP, 1986) and its "lack of coherence" (SOPHER, 1981; PARK, 1994). As Kong has argued persuasively, that geographical subfield is less fragmented than critics have claimed (KONG, 2001). In any case, agreement is over-rated. Diversity and complexity can enrich a subfield, as long as there is some minimal consent about the object of study. So continually work to self-consciously reflect on the subfield's constitutive

\footnotetext{
${ }^{5}$ For example, with disastrous social consequences, theories and interpretations informed by Aristotelian premises represented women as less than fully human and evolutionary models represented indigenous peoples as less than fully civilized.
} 
terms-religion and geography-but allow a range of approaches, both qualitative and quantitative. Leading scholars in both areas of study have understood their field as intrinsically cross-disciplinary (BAERWALD, 2010; TAVES, 2011), and specialists in this emerging interdisciplinary subfield can employ both historical and ethnographic analysis, which have been a part of the study of geography and religion, but they also might explore an even greater range of approaches from a variety of fields - cognitive science, archeology, literary analysis, performance studies, gender studies, ritual studies, art history, and media studies.

4. Encourage Disciplinary Diversity: It follows, then, that the study of geography and religion should draw on multiple disciplines in the humanities, social sciences, and natural sciences, even if not every scholar will do so and even if most scholarship might continue to be framed as contributions to Cultural Geography or Religious Studies. The subfield of geography and religion-and that phrase, as Chris Park argues, best acknowledges the complex relation between those two terms - should study religions as confluences of "organiccultural" processes. That means attending to both biology and culture, and including topics informed by both the natural sciences and the human sciences, from the neuroscience of spatial perception to the cultural variations in built environments. This methodological principle also suggests that the study of geography and religion moves back and forth between two primary fieldsGeography and Religious Studies - and specialists need to cross disciplinary boundaries to be informed in each, allowing the distinctive concerns of the other field to transform the scholar's perspective and generate new questions.

5. Celebrate Hyphenated Solutions: To deal with the most challenging issues it is usually best to employ the hyphen. Most debates in Geography and in Religious Studies are grounded in mistaken presuppositions that, in turn, frame the guiding questions in unhelpful ways. Most vexing theoretical and methodological questions can be framed more usefully as both-and and not either-or. We should be suspicious about simplistic accounts of differences and about standard classificatory binaries, however helpful they sometimes can be: for example, not only distinctions between fact and value and nature and culture, but also 
between physical and human geography, the individual and the group, structure and agency, inside and outside, interpretation and explanation, environmental freedom and determinism, and so on. On similar grounds, the widely recognized distinction (ISAAC, 1965; STUMP, 1986; PARK, 1994) between "religious geography" and "geography of religion" should be abandoned - or at least deemphasized. Scholars should analyze both religiously-informed imaginative maps and their effects on the landscape, as well as the ways that the terrain constrains, but does not determine, how humans imagine their place in the world. ${ }^{6}$

Even if you are not convinced that my theory of religion and its theoretical commitments might aid the study of geography and religion-I hope that you will at least consider the ways that this pragmatic perspective, with its emphasis on theoretical modesty, hyphenated framing, and methodological diversity, might offer compelling answers to some of the most fundamental questions facing this emerging interdisciplinary subfield. Or perhaps just this: I hope you find that this perspective raises helpful questions about theory and method. Pragmatism's ability to generate illuminating questions might be sufficient reason to welcome it into the crossdisciplinary conversation about geography and religion since, as I have suggested, subfields are animated, above all, by their questions.

\section{Acknowledgements}

I delivered an earlier version of this article as a public lecture at the University of Troms $\varnothing$ and as a plenary address at the University of Turku. I am grateful to graduate students and faculty colleagues at both institutions for their insightful questions and comments. I am indebted to geographers Carolyn Prorok and Michael Ferber for the original inspiration and the encouragement to show pragmatism's usefulness for the study of religion and geography. Later exchanges with Kim Knott, Steven Hoelscher, Lily Kong, and Scott Davis clarified my thinking and improved this article.

\section{REFERENCES}

6 For example, it is neither inevitable nor surprising that mountains became important in the religious cartography of Japanese religions. They were more likely to emerge as a venerated space and an orienting trope in those mountainous islands than in, say, among the cultures of Saharan Africa. 
ALLES, Gregory D. (ed). Religious Studies: A Global View. London and New York: Routledge, 2008.

AAR Annual Meeting Program Book. American Academy of Religion. Online Annual Meeting Program Book. San Diego, California, 2014.

ANTTONEN, Veikko. Rethinking the Sacred: The Notions of 'Human Body' and 'Territory' in Conceptualizing Religion. In: IDINOPULOS, Thomas A.; YONAN, Edward A. (eds). The Sacred and Its Scholars: Comparative Methodologies for the Study of Primary Religious Data. Leiden: E. J. Brill, 1996.

Space, Body, and the Notion of Boundary: A Category-Theoretical Approach to Religion. Temenos, Vol.41, No.2, 2005, p. 185-202.

Landscapes as Sacroscapes: Why Does Topography Make a Difference? In: NORDEIDE, S. Walaker; BRINK, Stephan (eds.). Sacred Sites and Holy Places: Exploring the Sacralization of Landscape through Time and Space. Turnhout: Brepols Publishers, 2013.

ANTTONEN, Veikko; HOLM, Nils G. (eds.). Editorial Note [Special issue on religion and geography]. Temenos, Vol.41, No.2, 2005, p.151-152.

APPADURAI, Arjun. Modernity at Large: Cultural Dimensions of Globalization. Minneapolis: University of Minnesota Press, 1996.

BAERWALD, Thomas J. Prospects for Geography as an Interdisciplinary Discipline. Presidential Address. Annals of the Association of American Geographers, Vol.100, No.3, 2010, p.493-501.

BETRAND, Jean-René et al. Religions et territories. Paris: L’Harmattan, 1999.

BHARDWAJ, Surinder Mohan. Hindu Places of Pilgrimage in India: A Study in Cultural Geography. Berkeley: University of California Press, 1973.

BOSTEELS, Bruno. A Misreading of Maps: The Politics of Cartography in Marxism and Poststructuralism. In: BARKER, Stephen (ed). Signs of Change. Albany: State University of New York Press, 1996.

BRAUN, Willi; MCCUTCHEON, Russell T. (eds.). Guide to the Study of Religion. London and New York: T \& T Clark, 2000.

BREMER, Thomas S. Blessed with Tourists: The Borderlands of Religion and Tourism in San Antonio. Chapel Hill: University of North Carolina Press, 2004.

CARNES, Tony, YANG, Fenggang (eds.). Asian American Religions: The Making and Remaking of Borders and Boundaries. New York: New York University Press, 2004.

CARROLL, Bret E. The Routledge Historical Atlas of Religion in America. New York and London: Routledge, 2000. 
CHIDESTER, David; LINENTHAL, Edward T. (eds.). American Sacred Space. Bloomington: Indiana University Press, 1995.

CLIFFORD, James. Routes: Travel and Translation in the Late Twentieth Century. Cambridge, Mass.: Harvard University Press, 1997.

CRANG, Mike; THRIFT, Nigel (eds.). Thinking Space. London and New York: Routledge, 2000.

DAVIE, Grace. Religion in Britain since 1945: Believing without Belonging. Oxford; Cambridge, Mass.: Blackwell, 1994.

DANDO, William A. Review of The Geography of Religion: Faith, Place, and Space, by Roger W. Stump. Professional Geographer, Vol.61, No.4, 2009, p.567-568.

DAVANEY, Sheila Greeve. Pragmatic Historicism: A Theology for the Twenty-First Century. Albany: State University of New York Press, 2000.

DAVIS, G. Scott. Richard Rorty and the Pragmatic Turn in the Study of Religion. Religion, Vol.39, 2009, p.69-82.

Believing and Acting: The Pragmatic Turn in Comparative Religion and Ethics. New York: Oxford University Press, 2012.

DEFFONTAINES, Pierre. Géographie et Religions. Paris: Gallimard, 1948.

ECK, Diana L. Banaras: City of Light. Princeton, New Jersey: Princeton University Press, 1998.

ELIADE, Mircea. The Sacred and the Profane: The Nature of Religion. New York: Harcourt Brace Jovanovich, 1959.

FELDHAUS, Anne. Connected Places: Region, Pilgrimage, and Geographical Imagination in India. New York: Palgrave Macmillan, 2003.

FRANKENBERRY, Nancy K. Pragmatism, Truth, and the Disenchantment of Subjectivity. In: ROSENBAUM, Stuart E. (ed.). Pragmatism and Religion: classical sources and original essays. Chicago-IL: University of Illinois Press, 2003.

FRAZIER, John W. Pragmatism: Geography and the Real World. In: HARVEY, Milton E.; HOLLY, Brian P. (eds.). Themes in Geographic Thought. New York: St. Martin's Press, 1981.

GAUSTAD, Edwin Scott; BARLOW, Philip L. New Historical Atlas of Religion in America. New York and Oxford: Oxford University Press, 2001.

GIL FILHO, Sylvio Fausto. Espaço Sagrado: Estudos em Geografia da Religião. Curitiba, Brazil: Ibpex, 2008. 
GILL, Sam. Territory. In: TAYLOR, Mark C. (ed.). Critical Terms for Religious Studies. Chicago: University of Chicago Press, 1998.

GOLD, Ann Grodzins. Fruitful Journeys: The Ways of Rajasthani Pilgrims. Berkeley: University of California Press, 1988.

GUPTA, Akhil; FERGUSON, James (eds.). Culture, Power, Place: Explorations in Critical Anthropology. Durham, N.C.: Duke University Press, 1997.

HABERMAN, David L. Journey through the Twelve Forests: An Encounter with Krishna. New York and Oxford: Oxford University Press, 1994.

HAACK, Susan. Vulgar Pragmatism: An Unedifying Prospect. In: HERMAN, J. (ed.). Rorty and Pragmatism: The Philosopher Responds to His Critics. Nashville, Tenn.: Vanderbilt University Press, 1995.

HAMNER, M. Gail. American Pragmatism: A Religious Genealogy. New York and Oxford: Oxford University Press, 2003.

HARAWAY, Donna. Situated Knowledges: The Science Question in Feminism and the Privilege of Partial Perspective. Feminist Studies, Vol. 14, No.3, 1988, p.575-599.

Routledge, 1991.

Simians, Cyborgs, and Women: The Reinvention of Nature. New York:

HART, William D. Edward Said and the Religious Effects of Culture. Cambridge: Cambridge University Press, 2000.

HERVIEU-LEGER, Danièle. La religion pour mémoire. Paris: Éditions du Cerf, 1993.

HINNELLS, John (ed.). The Routledge Companion to the Study of Religion. $2^{\text {nd }}$ ed. London and New York: Routledge, 2009.

HOLLINGER, Robert; DEPEW, David (eds.). Pragmatism: From Progressivism to Postmodernism. Westport, Conn.: Praeger, 1995.

HOLLOWAY, J.; VALINS, O. Editorial: Placing Religion and Spirituality in Geography. Social and Cultural Geography, Vol.3, No.1, 2002, p.5-9.

INDA, Jonathan Xavier; ROSALDO, Renato (eds.). The Anthropology of Globalization: A Reader. London: Blackwell, 2002.

ISAAC, Erich. Religious geography and the geography of religion. In: Man and the earth. University of Colorado Studies, Series in Earth Science No. 3. Boulder: University of Colorado Press, 1965.

JACKSON, Peter; SMITH, Susan J. Exploring Social Geography. London: George Allen and Unwin, 1984. 
JACOBSEN, Knut A. Processions, Public Space and Sacred Space in the South Asian Diasporas in Norway. In: JACOBSEN, Knut A. (ed.). South Asian Religions on Display: Religious Processions in South Asia and in the Diaspora. London and New York: Routledge, 2008.

JAMES, William. Pragmatism and Four Essays from The Meaning of Truth. Cleveland and New York: Meridian, 1955.

Philosophical Conceptions and Practical Results. An address delivered before the Philosophical Union at Berkeley, August 26, 1898. In: JAMES, William. Writings, 1878-1899, 1077-1097. New York: Library of America, 1992.

JOHNSTON, R. J.; GREGORY, Derek; PRATT, Geraldine; and WATTS, Michael (eds.). The Dictionary of Human Geography. $4^{\text {th }}$ ed. Oxford: Blackwell, 2000.

KAELL, Hillary. Walking Where Jesus Walked: American Christians and Holy Land Pilgrimage. New York: NYU Press, 2014.

KNOTT, Kim. The Location of Religion: A Spatial Analysis. London and Oakville, Ct.: Equinox, 2005.

Spatial Theory and the Study of Religion. Religion Compass, Vol.2, No.6, 2008, p.1102-1116.

Spatial Methods. In: STAUSBERG, Michael; ENGLER, Steven (eds.). The Routledge Handbook of Research Methods in the Study of Religion. London: Routledge, 2011.

KONG, Lily. Geography and Religion: Trends and Prospects. Progress in Human Geography, Vol.14, 1990, p.355-371.

Mapping 'New' Geographies of Religion: Politics and Poetics in Modernity. Progress in Human Geography, Vol.25, No.2, 2001, p.211-233. 2005, p.225-250.

Religious Processions: Urban Politics and Poetics. Temenos, Vol.41, No.2, Global Shifts, Theoretical Shifts: Changing Geographies of Religion. Progress in Human Geography, Vol.34, No.6, 2011, p.755-776.

KUKLICK, Bruce. A History of Philosophy in America, 1720-2000. New York and Oxford: Oxford University Press, 2001.

LAMBERTH, David. William James and the Metaphysics of Experience. Cambridge: Cambridge University Press, 1999.

LANE, Belden C. Landscapes of the Sacred: Geography and Narrative in American Spirituality. New York: Paulist Press, 1988. 
Giving Voice to Place: Three Models for Understanding American Sacred Space. Religion and American Culture, Vol.11, No.1, 2001, p.53-81.

LEVINE, Gregory J. On the Geography of Religion. Transactions of the Institute of British Geographers, Vol.11, 1987, p.428-440.

LEVINSON, Henry S. The Religious Investigations of William James. Chapel Hill: University of North Carolina Press, 1981.

LINENTHAL, Edward Tabor. Sacred Ground: Americans and Their Battlefields. Urbana: University of Illinois Press, 1991.

Preserving Memory: The Struggle to Create America's Holocaust Museum. New York: Penguin Books, 1997.

The Unfinished Bombing: Oklahoma City in American Memory. New York and Oxford: Oxford University Press, 2001.

LOVEJOY, Arthur O. The Thirteen Pragmatisms. Journal of Philosophy, Psychology, and Scientific Methods, Vol.5, No.1, 1908, p.229-39.

ORSI, Robert A. (ed.). Gods of the City. Bloomington: Indiana University Press, 1999.

MENAND, Louis. The Metaphysical Club. New York: Farrar, Straus, and Giroux, 2001.

MOONEY, Margarita. Faith Makes Us Live: Surviving and Thriving in the Haitian Diaspora. Berkeley: University of California Press, 2009.

OLSON, E.; SILVEY, R. Transnational Geographies: Rescaling Development, Migration, and Religion. Environment and Planning, Vol.38, 2006, p.805-808.

PARK, Chris C. Sacred Worlds: An Introduction to Geography and Religion. London and New York: Routledge, 1994.

PARK, Robert Ezra; BURGESS, Ernest W. Introduction to the Science of Sociology. Chicago: University of Chicago Press, 1921.

PAUKETAT, Timothy. Resettled Farmers and the Making of a Mississippian Polity. American Antiquity, Vol.68, No.1, 2003, p.39-66.

PEIRCE, Charles S. How to Make Our Ideas Clear. Popular Science Monthly, Vol.12, 1878, p.286-302.

PROCTOR, James. Introduction: Theorizing and Studying Religion. Annals of the Association of American Geographers, Vol.96, No.1, 2006, p.165-168.

PROUDFOOT, Wayne. Religious Experience. Berkeley: University of California Press, 1985. 
PUTNAM, Hilary. Reason, Truth, and History. Cambridge: Cambridge University Press, 1981. 1990.

Realism with a Human Face. Cambridge, Mass.: Harvard University Press,

The Collapse of the Fact/Value Dichotomy and Other Essays. Cambridge, Mass.: Harvard University Press, 2002.

READER, Ian. Making Pilgrimages: Meaning and Practice in Shikoku. Honolulu: University of Hawai' $i$ Press, 2005.

RHOADS, Bruce L. Beyond Pragmatism: The Value of Philosophical Discourse for Physical Geography. Annals of the Association of American Geographers, Vol.89, No.4, 1999, p.760-771.

RINSCHEDE, Gisbert. Religionsgeographie. Braunschweig: Westermann, 1999.

ROCHA, Cristina; VÁSQUEZ, Manuel A. O Brazil na Nova Cartografia Global da Religião. Religião e Sociedade, Rio de Janeiro, Vol.34, No.1, 2014, p.13-37.

RORTY, Richard. Philosophy and the Mirror of Nature. Princeton, New Jersey: Princeton University Press, 1979.

. Religion in the Public Square: A Reconsideration. Journal of Religious Ethics, Vol.31, No.1, 2003, p.141-149.

ROSE, Gillian. Situating Knowledges: Positionality, Reflexivities, and Other Tactics. Progress in Human Geography, Vol.21, No.3, 1997, p.305-320.

ROSENBAUM, Stuart (ed.). Pragmatism and Religion. Urbana: University of Illinois Press, 2003.

RUTHERFORD, Ian. Theōria and Darśan: Pilgrimage and Vision in Greece and India. Classical Quarterly, Vol.50, No.1, 2000, p.133-146.

SAYER, R. Andrew. Space and Social Theory. In: SAYER, R. Andrew. Realism and Social Science. London: Sage, 2000.

SEGAL, Robert A. (ed.). The Blackwell Companion to the Study of Religion. Malden, Mass. and Oxford: Blackwell, 2006.

SHARF, Robert H. Experience. In: TAYLOR, Mark C. (ed.). Critical Terms for Religious Studies. Chicago: University of Chicago Press, 1998.

SMITH, Christian. Moral, Believing Animals: Human Personhood and Culture. New York and Oxford: Oxford University Press, 2003.

SMITH, Jonathan Z. (ed.). The HarperCollins Dictionary of Religion. New York: HarperCollins, 1995. 
Relating Religion: Essays in the Study of Religion. Chicago: University of

Chicago Press, 2004.

SMITH, Susan J. Practicing Humanistic Geography. Annals of the Association of American Geographers, Vol.74, No.3, 1984, p.353-374.

SOJA, Edward W. Postmodern Geographies: The Reassertion of Space in Critical Social Theory. London: Verso, 1989.

SOPHER, David E. Geography of Religions. Englewood Cliffs, N.J.: Prentice-Hall, 1967. p.510-524.

Geography and Religion. Progress in Human Geography, Vol.5, 1981,

STAUSBERG, Michael. Introduction: Exploring the Meso-levels of Religious Mappings: European Religion in Regional, Urban, and Local Contexts. Religion, Vol.39, 2009, p.103-109.

STOUT, Jeffrey. Democracy and Tradition. Princeton, N.J.: Princeton University Press, 2004.

STUMP, Roger W. The Geography of Religion: Introduction. Journal of Cultural Geography, Vol.7, 1986, p.1-3.

The Geography of Religion: Faith, Place, and Space. Lanham, Md.: Rowman and Littlefield, 2008.

SUNLEY, Peter. Context in Economic Geography: The Relevance of Pragmatism. Progress in Human Geography, Vol.20, No.3, 1996, p.338-355.

TAVES, Ann. Religious Experience Reconsidered: A Building-Block Approach to the Study of Religion and Other Special Things. Princeton, N.J.: Princeton University Press, 2009.

. "Religion" in the Humanities and the Humanities in the University. Presidential Address. Journal of the American Academy of Religion, Vol.79, No.2, 2011, p.287314.

THAYER, H. Standish. Pragmatism. In: Encyclopedia Britannica, 2010. Disponível em: <http://search.eb.com.ezproxy.lib.utexas.edu/eb/article-68590> Acesso: 7 Jan. 2014.

TUAN, Yi-Fu. Humanistic Geography. Annals of the Association of American Geographers, Vol.66, 1976, p.266-276.

Space and Place: The Perspective of Experience. Minneapolis: University of Minnesota Press, 1977.

TWEED, Thomas A. Our Lady of the Exile: Diasporic Religion at a Cuban Catholic Shrine in Miami. New York and Oxford: Oxford University Press, 1997. 
John Wesley Slept Here: American Shrines and American Methodists. Numen, Vol.47, 2000, p.41-68.

American Occultism and Japanese Buddhism: Albert J. Edmunds, D.T. Suzuki, and Translocative History. Japanese Journal of Religious Studies, Vol.32, No.2, 2005, p.249-81.

Crossing and Dwelling: A Theory of Religion. Cambridge, Mass.: Harvard University Press, 2006.

. Space. Material Religion: The Journal of Objects, Art, and Belief, Vol.7, No.1, 2011, p.116-123.

Following the Flows: Diversity, Santa Fe, and Method in Religious Studies. In: PHAN, Peter C.; RAY, Jonathan S. (eds.). Understanding Religious Pluralism: Perspectives from Religious Studies and Theology. Eugene, Oregon: Pickwich, 2014.

VAN DER LEEUW, Gerardus. Religion in Essence and Manifestation. Princeton: Princeton University Press, 1986.

VINCENT, Jeanne-Françoise et al. La construction religieuse du territoire. Paris: L'Harmattan, 1995.

WARNER, R. Stephen; WITTNER, Judith G. (eds.). Gatherings in Diaspora: Religious Communities and the New Immigration. Philadelphia, Pa.: Temple University Press, 1998.

WEST, Cornell. The American Evasion of Philosophy: A Genealogy of Pragmatism. Madison: University of Wisconsin Press, 1989.

WIENER, P. P. Evolution and the Founders of Pragmatism. Cambridge, Mass.: Harvard University Press, 1949.

WRIGHT, John K. Human Nature in Geography: Fourteen Papers, 1925-1965. Cambridge, Mass.: Harvard University Press, 1966.

Recebido: $12 / 06 / 2014$

Received: 06/12/2014

Aprovado: 19/10/2014

Approved: 10/19/2014 